\title{
INDEX TO VOLUME 47 (2009)
}

\section{ARTIGLES}

'Against the Asian tide: the Sudan divestment campaign' by Luke A. PAtey, 4, $55^{\mathrm{I}-73}$

'Ambiguous elections: the influence of non-electoral politics in Ethiopian democratisation' by KJETIL Tronvoll, 3, 449-74

ARIEFF, AlEXIs, 'Still standing: neighbourhood wars and political stability in Guinea', 3, 33 ${ }^{\mathrm{I}-48}$

Baines, Erin K., 'Complex political perpetrators: reflections on Dominic Ongwen', 2, I63-9I

Bauer, Jacqui, 'Women and the 2005 Election in Liberia', 2, I93-2II

'Becoming a bwana and burley tobacco in the Central Region of Malawi' by Martin Prowse, 4, 575-602

Bolten, Catherine, 'Rethinking burgeoning political consciousness: student activists, the Class of '99 and political intent in Sierra Leone', 3, 349-69

Cavatorta, Francesco and Emanuela Dalmasso, 'Liberal outcomes through undemocratic means: the reform of the Code de statut personnel in Morocco', $4,487-506$

'Complex political perpetrators: reflections on Dominic Ongwen' by ERIN K. Baines, 2, i63-9I

'A constructed (un)reality on China's re-entry into Africa: the Chinese online community perception of Africa (2006-2008)' by Simon SHEN, 3, 425-48

" "Does the truth pass across the fire without burning?" Locating the short circuit in Rwanda's Gacaca courts' by BERT Ingelaere, 4, 507-28

Fekadu Beyene, 'Property rights conflict, customary institutions and the state: the case of agro-pastoralists in Mieso district, eastern Ethiopia', 2, 213-39

Fjeldstad, Odd-Helge and Mick Moore, 'Revenue authorities and public authority in sub-Saharan Africa', I, I-I8

'Forced labour in Eritrea' by Gaim Kibreab, I, 4I-72

Fridy, Kevin S. and Victor Brobbey, 'Win the match and vote for me: the politicisation of Ghana's Accra Hearts of Oak and Kumasi Asante Kotoko football clubs', I, I9-39

Ingelaere, Bert, "Does the truth pass across the fire without burning?" Locating the short circuit in Rwanda's Gacaca courts', 4, 507-28

Kibreab, Gaim, 'Forced labour in Eritrea', I, 4I-72

KLANTSChNig, Gernot, 'The politics of law enforcement in Nigeria: lessons from the war on drugs', $4,529-49$

Lawson, Letitia, 'The politics of anti-corruption reform in Africa', I, 73-Ioo

'Liberal outcomes through undemocratic means: the reform of the Code de Statut Personnel in Morocco' by Francesco Cavatorta and Emanuela Dalmasso, $4,487-506$

Logan, Carolyn, 'Selected chiefs, elected councillors and hybrid democrats: popular perspectives on the co-existence of democracy and traditional authority', I, IOI-28 
Marysse, Stefaan and Sara Geenen, 'Win-win or unequal exchange? The case of the Sino-Congolese "cooperation" agreements', 3, 37 I-96

"The "Masai" and "miraa": public authority, vigilance and criminality in a Ugandan border town' by KRISTOF TitecA, 2, 29I-3I7

Meagher, Kate, 'Trading on faith: religious movements and informal economic governance in Nigeria', 3, 397-423

N'Diaye, Boubacar, 'To "midwife" - and abort - a democracy: Mauritania's transition from military rule, 2005-2008', I, I29-52

Okafor, Obiora Chinedu, 'Remarkable returns: the influence of a labour-led socio-economic rights movement on legislative reasoning, process and action in Nigeria, I999-2007', 2, 24I-66

Patey, Luke A., 'Against the Asian tide: the Sudan divestment campaign', 4, $55^{\mathrm{I}-73}$

'The Peace and Security Council of the African Union: evaluating an embryonic international institution' by Paul D. Williams, 4, 6o3-26

'The politics of anti-corruption reform in Africa' by Letitia Lawson, I, 73-IOO

'The politics of law enforcement in Nigeria: lessons from the war on drugs' by Gernot Klantschnig, 4, 529-49

'Property rights conflict, customary institutions and the state: the case of agropastoralists in Mieso district, eastern Ethiopia' by FeKadu Beyene, 2, 2 I3-39

Prowse, Martin, 'Becoming a bwana and burley tobacco in the Central Region of Malawi', 4, 575-602

'Remarkable returns: the influence of a labour-led socio-economic rights movement on legislative reasoning, process and action in Nigeria, I999-2007' by Obiora Ghinedu Okafor, 2, 24I-66

'Rethinking burgeoning political consciousness: student activists, the Class of '99 and political intent in Sierra Leone' by Catherine Bolten, 3, 349-69

'Revenue authorities and public authority in sub-Saharan Africa' by OdD-Helge FJeldstad and Mick Moore, I, I-I8

Rubbers, Benjamin, 'The story of a tragedy: how people in Haut-Katanga interpret the post-colonial history of Congo', 2, 267-89

'Selected chiefs, elected councillors and hybrid democrats: popular perspectives on the co-existence of democracy and traditional authority' by CAROLYN LOGAN, I, IOI-28

Shen, Simon, A 'constructed (un)reality on China's re-entry into Africa: the Chinese online community perception of Africa (2006-2008)', 3, 425-48

'Still standing: neighbourhood wars and political stability in Guinea' by Alexis ARIEFF, 3, 33 ${ }^{\mathrm{I}-48}$

'The story of a tragedy: how people in Haut-Katanga interpret the post-colonial history of Congo' by Benjamin RubBers, 2, 267-89

Titeca, Kristof, "The "Masai" and "miraa": public authority, vigilance and criminality in a Ugandan border town', 2, 29I-3I7

"To "midwife" - and abort - a democracy: Mauritania's transition from military rule, 2005-2008' by Boubacar N'Diaye, i, i29-52

'Trading on faith: religious movements and informal economic governance in Nigeria’ by Kate Meagher, 3, 397-423 
Tronvold, KJetil, 'Ambiguous elections: the influence of non-electoral politics in Ethiopian democratisation', 3, 449-74

Williams, Paul D., 'The Peace and Security Council of the African Union: evaluating an embryonic international institution', 4, 603-26

'Win the match and vote for me: the politicisation of Ghana's Accra Hearts of Oak and Kumasi Asante Kotoko football clubs' by Kevin S. Fridy and Victor BrobBey, I, I9-39

"Win-win or unequal exchange? The case of the Sino-Congolese "cooperation" agreements' by StefaAn Marysse and SARa Geenen, 3, 37I-96

'Women and the 2005 Election in Liberia' by JACQUi BAUER, 2, I93-2I I

\section{REVIEWS}

Adama, Onyanta, Governing from Above: solid waste management in Nigeria's new capital city of Abuja, reviewed by Joost Beuving, 3, 475

Africa and the North: between globalization and marginalization edited by ULF ENGEL and GORM RYE Olsen, reviewed by Graham Harrison, 2, 322

African Development: making sense of the issues and actors by ToDD J. Moss, reviewed by Timothy M. Shaw, 3, 480

African Pentecostalism: an introduction by O. KaLU, reviewed by Ben Jones, 4, 632

Agricultural Trade Liberalization and the Least Developed Countries edited by NieK KonIng and Per Pinstrup-Andersen, reviewed by Mark Langan, 2, 324

Aidoo, Richard, review of Crouching Tiger, Hidden Dragon? Africa and China edited by Kweku Ampiah and Sanusha Naidu, 4, 628

Alao, Abiodun, Natural Resources and Conflict in Africa: the tragedy of endowement, reviewed by Mats Berdal, 4, 627

Ampiah, Kweku and Sanusha Naidu, editors, Crouching Tiger, Hidden Dragon? Africa and China, reviewed by Richard Aidoo, 4, 628

Apartheid and Beyond: South African writers and the politics of place by RITA BARNARD, reviewed by Andrew Offenburger, 2, 319

Argenti, N., The Intestines of the State: youth, violence, and belated histories in the Cameroon Grassfields, reviewed by Krijn Peters, 4, 630

Baker, Bruce, Multi-Choice Policing in Africa, reviewed by Helene Maria Kyed, I, I54

BARnard, Rita, Apartheid and Beyond: South African writers and the politics of place, reviewed by Andrew Offenburger, 2, 319

Bayliss, Kate and Ben Fine, Privatization and Alternative Public Sector Reform in Sub-Saharan Africa: delivering on electricity and water, reviewed by Alex Loftus, I, I55

Berdal, Mats, review of Natural Resources and Conflict in Africa: the tragedy of endowment by Abiodun Alao, 4, 627

Beswick, Danielle, review of Killing Neighbors: webs of violence in Rwanda by LEE ANN FuJI, 4, 63I

Beuving, Joost, review of Governing from Above: solid waste management in Nigeria's new capital city of Abuja by OnYanta Adama, 3, 475

Butler, Anthony, Cyril Ramaphosa, reviewed by Heather Deegan, 2, 320

Conflicts over Land and Water in Africa edited by B. Derman, R. Odgand and E. SJaAstad, reviewed by Joost Fontein, 3, 476

Constructive Engagement? Chester Crocker and American policy in South Africa, Namibia and Angola I98I- 8 by J. E. Davies, reviewed by Alex Thomson, I, I58

Cooper, Barbara M., Evangelical Christians in the Muslim Sahel, reviewed by Ogbu U. Kalu, 2,321

Cox, James L., review of The Living Dead and the Living God: Christ and the ancestors in a changing Africa by KLAUS NÜRNBERGER, 2, 326 
Critical Reflections on the Eritrean War of Independence: social capital, associational life, religion, ethnicity and sowing the seeds of dictatorship by GAIM KIBREAB, reviewed by Richard Reid, 3,479

Crouching Tiger, Hidden Dragon? Africa and China edited by Kweku Ampiah and Sanusha NAIDU, reviewed by Richard Aidoo, 4, 628

Cyril Ramaphosa by Anthony Butler, reviewed by Heather Deegan, 2, 320

Daley, Patricia O., Gender \& Genocide in Burundi: the search for spaces of peace in the Great Lakes region, reviewed by Mathijs van Leeuwen, I, I56

Davies, J. E., Constructive Engagement? Chester Crocker and American policy in South Africa, Namibia and Angola $1981-8$, reviewed by Alex Thomson, I, I58

Deegan, Heather, review of Cyril Ramaphosa by ANTHOny Butler, 2, 320

Derman, B., R. OdgaArd and E. SJaAstad, editors, Conflicts over Land and Water in Africa, reviewed by Joost Fontein, 3, 476

A Dialogue of the Deaf: essays on Africa and the United Nations edited by Adereye Adebajo and Helen Scanlon, reviewed by Kate Seaman, I, I53

Dibua, Jeremiah I., Modernization and the Crisis of Development in Africa: the Nigerian experience, reviewed by Amidu Olalekan Sanni, 3, 478

Duffy, Rosaleen, review of Madagascar: a short history by Solofo Randrianja and STEPHEN ELLIS, 4,634

Economic Development of Southern Sudan by Benaiah Yongo-Bure, reviewed by Mark Leopold, 2,328

Engel, Ulf and Gorm Rye Olsen, editors, Africa and the North: between globalization and marginalization, reviewed by Graham Harrison, 2, 322

Evangelical Christians in the Muslim Sahel by BARBARA M. COOPER, reviewed by Ogbu U. Kalu, 2, $32 \mathrm{I}$

Falola, Toyin and Matthew H. Heaton, editors, HIV/AIDS, Illness, and African WellBeing, reviewed by Sophie Harman, I, I59

Fontein, Joost, review of Conflicts over Land and Water in Africa edited by B. Derman, R. OdgaArd and E. SJaAstad, 3, 476

FujI, Lee Ann, Killing Neighbors: webs of violence in Rwanda, reviewed by Danielle Beswick, $4,63 \mathrm{I}$

Gender $\mathcal{E}^{\mathcal{O}}$ Genocide in Burundi: the search for spaces of peace in the Great Lakes region by PATRICIA O. DALEY, reviewed by Mathijs van Leeuwen, I, I56

Glover, Dominic, review of Starved for Science: how biotechnology is being kept out of Africa by Robert Paarlberg, 3, 485

Governing from Above: solid waste management in Nigeria's new capital city of Abuja by ONYANTA ADAMA, reviewed by Joost Beuving, 3, 475

Harman, Sophie, review of HIV/AIDS, Illness, and African Well-Being edited by ToyIN Falola and Matthew H. Heaton, i, i59

Harrison, Graham, review of Africa and the North: between globalization and marginalization edited by Ulf Engel and Gorm Rye Olsen, 2, 322

HatzFeld, JeAn, Life Laid Bare: the survivors in Rwanda speak, reviewed by Paul J. Magnarella, I, I6o

HIV/AIDS, Illness, and African Well-Being edited by Toyin Falola and MatThew $\mathrm{H}$. Heaton, reviewed by Sophie Harman, I, I59

The Intestines of the State: youth, violence, and belated histories in the Cameroon Grassfields by N. Argenti, reviewed by Krijn Peters, 4, 630

Jones, Ben, review of African Pentecostalism: an introduction by O. Kalu, 4, 632

Kalu, O., African Pentecostalism: an introduction, reviewed by Ben Jones, 4, 632

Kalu, Ogbu U., review of Evangelical Christians in the Muslim Sahel by Barbara M. Cooper, 2, $32 \mathrm{I}$

Kenya's Quest for Democracy: taming Leviathan by MaKau Mutua, reviewed by Myles Osborne, $3,48 \mathrm{I}$ 


\section{REVIEWS}

KIBREAB, GAIM, Critical Reflections on the Eritrean War of Independence: social capital, associational life, religion, ethnicity and sowing the seeds of dictatorship, reviewed by Richard Reid, 3, 479

Killing Neighbors: webs of violence in Rwanda by LeE AnN FujI, reviewed by Danielle Beswick, $4,63 \mathrm{I}$

Koning, Niek and Per Pinstrup-Andersen, editors, Agricultural Trade Liberalization and the Least Developed Countries, reviewed by Mark Langan, 2, 324

Kyed, Helene Maria, review of Multi-Choice Policing in Africa by BRUCE BAKer, I, I54

Langan, Mark, review of Agricultural Trade Liberalization and the Least Developed Countries edited by Niek Koning and Per Pinstrup-Andersen, 2, 324

Leopold, Mark, review of Economic Development of Southern Sudan by Benaiah Yongo-Bure, 2, 328

Life Laid Bare: the survivors in Rwanda speak by JeAn HatzFeld, reviewed by Paul J. Magnarella, I, I6o

The Living Dead and the Living God: Christ and the ancestors in a changing Africa by KLAUS NÜRnberger, reviewed by James L. Cox, 2, 326

Loftus, Alex, review of Privatization and Alternative Public Sector Reform in Sub-Saharan Africa: delivering on electricity and water by Kate BaYLISS and BEN FInE, I, I55

Madagascar: a short history by SOlofo RandRianja and STEPHEn Eldis, reviewed by Rosaleen Duffy, 4, 634

Magnarella, Paul J., review of Life Laid Bare: the survivors in Rwanda speak by JeAn HaTZFELD, I, I60

Modernization and the Crisis of Development in Africa: the Nigerian experience by JeremiaH I. Dibua, reviewed by Amidu Olalekan Sanni, 3, 478

Moss, TodD J., African Development: making sense of the issues and actors, reviewed by Timothy M. Shaw, 3, 480

Multi-Choice Policing in Africa by Bruce BaKer, reviewed by Helene Maria Kyed, I, I54

Mutua, Akau, Kenya's Quest for Democracy: taming Leviathan, reviewed by Myles Osborne, 3, $48 \mathrm{I}$

Natural Resources and Conflict in Africa: the tragedy of endowment by ABIODUn AlaO, reviewed by Mats Berdal, 4, 627

Núrnberger, Klaus, The Living Dead and the Living God: Christ and the ancestors in a changing Africa, reviewed by James L. Cox, 2, 326

Offenburger, Andrew, review of Apartheid and Beyond: South African writers and the politics of place by Rita BARNARD, 2, 319

Olonisakin, Funmi, Peacekeeping in Sierra Leone: the story of UNAMSIL, reviewed by Andreu Sola-Martin, I, I6 I

Osborne, Myles, review of Kenya's Quest for Democracy: taming Leviathan by MaKau Mutua, $3,48 \mathrm{I}$

Ostien, P., editor, Sharia Implementation in Northern Nigeria 1999-20o6: a sourcebook, reviewed by Rotimi Suberu, 3, 483

PaArlberg, Robert, Starved for Science: how biotechnology is being kept out of Africa, reviewed by Dominic Glover, 3, 485

Peacekeeping in Sierra Leone: the story of UNAMSIL by Funmi OLONISAKIn, reviewed by Andreu Sola-Martin, I, I6 I

Peters, Krijn, review of The Intestines of the State: youth, violence, and belated histories in the Cameroon Grassfields by N. ARgenti, 4, 630

Privatization and Alternative Public Sector Reform in Sub-Saharan Africa: delivering on electricity and water by KATE BAYLISS and BEN FINE, reviewed by Alex Loftus, I, I55

Randrianja, Solofo and Stephen Eldis, Madagascar: a short history, reviewed by Rosaleen Duffy, 4, 634

Reid, Richard, review of Critical Reflections on the Eritrean War of Independence: social capital, associational life, religion, ethnicity and sowing the seeds of dictatorship by GAIM KIBREAB, 3, 479 
Sanni, Amidu Olalekan, review of Modernization and the Crisis of Development in Africa: the Nigerian experience by Jeremiah I. Dibua, 3,478

Senghor, Jeggan C. and Nana Poku, editors, Towards Africa's Renewal, reviewed by Fredrik Söderbaum, 2, 327

Sharia Implementation in Northern Nigeria 1999-2006: a sourcebook edited by P. OstiEN, reviewed by Rotimi Suberu, 3, 483

Shaw, Timothy M., review of African Development: making sense of the issues and actors by TodD J. Moss, 3,480

Söderbaum, Fredrik, Towards Africa's Renewal, edited by Jeggan C. Senghor and Nana Poku, 2, 327

Sola-Martin, Andreu, review of Peacekeeping in Sierra Leone: the story of UNAMSIL by FUNMI Olonisakin, I, i6 I

Starved for Science: how biotechnology is being kept out of Africa by RoBERT PAARLBERG, reviewed by Dominic Glover, 3, 485

Suberu, Rotimi, review of Sharia Implementation in Northern Nigeria 1999-20o6: a sourcebook edited by P. Ostien, 3, 483

Thomson, Alex, review of Constructive Engagement? Chester Crocker and American policy in South Africa, Namibia and Angola $19^{8} I_{-}-8$ by J. E. DAvies, I, I58

Towards Africa's Renewal, edited by Jeggan C. Senghor and Nana Poku, reviewed by Fredrik Söderbaum, 2, 327

van Leeuwen, Mathijs, review of Gender $\mathcal{E}^{\mathcal{E}}$ Genocide in Burundi: the search for spaces of peace in the Great Lakes region by PATRicia O. Daley, I, I56

Yongo-Bure, Benaiah, Economic Development of Southern Sudan, reviewed by Mark Leopold, 2, 328 


\section{CAMBRIDGE}

\section{JUURNALS}

\section{journals.cambridge.org Advancing research. Increasing access.}

Informed by detailed consultation with the library and research communities, we are constantly developing our industry-leading online journals platform.

Some recent advances include:

- Refreshed site design, facilitating rapid access to the most relevant content.

- New advanced search interface and a more detailed, fielded quick search function.

- Enriched content in the form of multimedia companions and editorial blogs.

- The launch of Cambridge Open Option, our open access initiative.

Visit journals.cambridge.org/openoption for more information. 


\section{Advertising Opportunities}

To advertise in this journal and for details of pricing, availability and discount opportunities please contact:

\section{Advertising in UK, Europe and rest of world}

\section{The Advertising Sales Team}

Cambridge University Press

The Edinburgh Building,

Shaftesbury Road,

Cambridge, UK, CB2 8RU

Tel: +44 (0)1223 325083

Email: ad_sales@cambridge.org

\section{Advertising in USA, Mexico and Canada}

Journals Advertising Coordinator

32 Avenue of the Americas,

New York,

NY 10013-2473, USA

Tel: +1 (212) 3375053 Fax: +1 (212 337 5959)

E-mail: journals_advertising@cambridge.org 


\section{CONTRIBUTIONS}

The Fournal of Modern African Studies offers a quarterly survey of developments in modern African politics and society. It seeks to publish original empirical research, which helps to illuminate broader issues affecting Africa. Papers derived from fieldwork in Africa are particularly welcome. Its main emphasis is on current issues in African politics, economies, societies, and international relations, seeking to benefit from the work of specialists in different academic disciplines, and of those who are currently engaged in the affairs of the continent. Historical studies will normally be accepted only when they are directly relevant to the understanding of modern Africa.

The fournal, which is fully refereed, seeks to promote a deeper understanding of what is happening in Africa today. It is intended not only for students and academic specialists, but also for general readers and practitioners with a concern for modern Africa, living and working both inside and outside the continent. Contributions should therefore be presented in such a way as to be accessible to any informed and interested reader, and papers which take a narrowly technical or disciplinary approach will not be accepted.

Editorial policy avoids commitment to any political viewpoint or ideology, recognising that a wide range of different approaches are needed in order to understand developments in Africa, and that approaches which are unfashionable at one moment may well become widely accepted at another. Controversial papers, and papers which seek to challenge current orthodoxies, are therefore welcome, subject only to the recognition that the purpose of the Fournal is to promote understanding, rather than to act as the mouthpiece for polemic.

Contributors are invited from all over the world, and those from scholars and practitioners working in Africa are particularly welcome. Articles should not be longer than 10,000 words, including references and notes. Articles submitted to the fournal should be original contributions and not under consideration for any other publication at the same time. Exceptions to this rule should be clearly indicated at the time of submission. Following publication, authors are entitled to republish their articles elsewhere, in original or amended form, provided that prior publication in The Journal of Modern African Studies is acknowledged.

All correspondence and contributions should be addressed to:

Christopher Clapham, African Studies Centre, Free School lane, Cambridge cb2 3Ro, United Kingdom, or by email to csc34@cam.ac.uk

Email attachments should be in Word. Alternatively, contributors should submit three copies to the Editor. Contributors working in Afiica need only send one copy. The author's name, address and institutional affiliation (where appropriate), and any other identifying material, should be provided on a cover page, and excluded from the main text, so as to ensure anonymity. Jointly authored papers should identify a single author, with whom all correspondence will be conducted. Manuscripts will not be returned to authors.

Contributors will receive a copy of the issue in which their article appears, plus a pdf file of their published paper.

Contributors to this fournal express their own opinions, which should not be interpreted as the official view of any institution or organisation with which they may be connected.

This journal issue has been printed on FSC-certified paper and cover board. FSC is an independent, non-governmental, not-for-profit organization established to promote the responsible management of the world's forests. Please see www.fsc.org for information.

\section{CAMBRIDGE UNIVERSITY PRESS}

The Edinburgh Building, Shaftesbury Road, Cambridge CB2 8RU 32 Avenue of the Americas, New York, NY 1oor3-2473, USA

477 Williamstown Road, Port Melbourne, vic 3207, Australia Ruiz de Alarcón I3, 280I4 Madrid, Spain

Dock House, The Waterfront, Cape Town 8oor, South Africa 


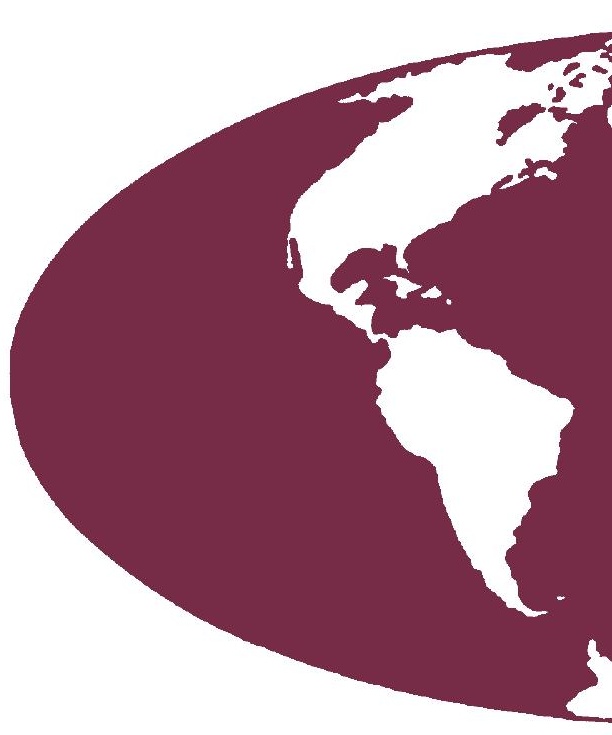

Cambridge Journals Online

For further information about this journal

please go to the journal website at:

journals.cambridge.org/moa

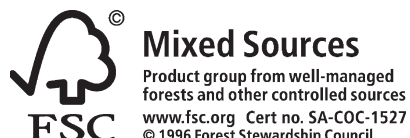

CAMBRIDGE UNIVERSITY PRESS 